\title{
GOMMENTS
}

\section{IMPLEMENTATION AND POLICY: PROBLEMS IN THE APPLICATION OF COUNTERVAILING DUTY LAWS TO NONMARKET ECONOMY COUNTRIES}

\author{
ROBERT FRANKLIN HOYT $\dagger$
}

\section{INTRODUCTION}

The ostensible goal of United States trade law is to promote freemarket principles. The ideal espoused is maximum market efficiency, achieved when free trade allows each country to specialize by exporting those goods it can produce most efficiently and importing those goods that it can produce only at a higher cost. ${ }^{1}$ To the extent that foreign countries and producers exporting goods to the United States undermine this ideal by failing to comply with the free-market standard imposed by United States law, their actions are deemed "unfair" trade practices. ${ }^{2}$ Over the past one hundred years, the United States has developed a complex body of laws to protect domestic industries from these unfair practices. ${ }^{3}$ Foremost among these "unfair trade relief mea-

† B.S. 1986, Cornell University; A.M. Candidate 1989, University of Pennsylvania; J.D. Candidate 1989, University of Pennsylvania. This Comment is dedicated to Robert J. Hoyt for providing me with a lifetime of inspiration.

1 See Comptroller General of the U.S., General Accounting Office,

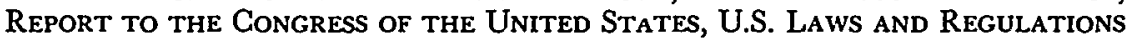
Applicable to IMPORTS from Nonmarket Economies CoUld Be IMPROVEd 5 (1981) [hereinafter GAO REPORT TO THE Congress]; Barceló, Subsidies and Countervailing Duties-Analysis and a Proposal, 9 LAw \& PoL'y INT'L Bus. 779, 786-88 (1977); Tarullo, Beyond Normalcy in the Regulation of International Trade, 100 HaRv. L. REv. 546, 549-51 (1987); Note, An Argument for Freer Trade: The Nonmarket Economy Problem Under the U.S. Countervailing Duty Laws, 17 N.Y.U.J. INT'L L. \& Pol. 407, 430 (1985). See generally P. SAMuelson, Economics 626-30 (11th ed. 1980) (explaining the theory of comparative advantage).

2 See Tarullo, supra note 1, at 552-53.

3 See J. Pattison, Antidumping and Countervailing Duty Laws $\$ \S 1.01$, 1.03-1.04 (International Business \& Law Series No. 3, 1987) (discussing the development of modern antidumping and countervailing duty laws). These unfair trade relief measures are distinct from import relief measures, such as section 201 of the Trade Act of 1974, Pub. L. No. 93-618, tit. II, $\S \S 201-08,88$ Stat. 1978, 2011-18 (1975) (codi- 
sures" are antidumping ${ }^{4}$ and countervailing duty laws, ${ }^{5}$ which attempt to equalize competitive conditions that have been distorted by dumped or subsidized imports. ${ }^{6}$

The free-market principles underlying United States trade law create difficulties in trade relations with nonmarket economy countries. ${ }^{7}$ Many of these difficulties center on whether those principles can be translated and applied to trade with nonmarket economy countries.

To facilitate enforcement of the antidumping law against nonmarket economy countries, Congress enacted legislation requiring the Department of Commerce to circumvent the problem of the absence of reliable price information by constructing that information hypothetically through reference to data available in surrogate countries with

fied as amended at 19 U.S.C. $§ 2251$ (1982 \& Supp. IV 1986)) (providing for temporary restrictions on imports that, because of their increasing volume, are injuring domestic industries and workers), or section 406 of the Trade Act of 1974, Pub. L. No. 93-618, tit. IV, $\S 406(c), 88$ Stat. 1978, 2062-63 (1975) (codified at 19 U.S.C. $\S 2436$ (c) (1982)) (providing for relief from imports from communist countries when those imports disrupt domestic markets and cause material injury to domestic industries or unions). See GAO REPORT TO THE CONGRESS, supra note 1, at 7-8.

4 See 19 U.S.C. § 1673-1673i (1982 \& Supp. IV 1986). Dumping is a form of international price discrimination whereby a producer charges a lower price for its product in a foreign market than it charges for the product in its domestic market. See J. Viner, Dumping: A Problem in International Trade 3 (1923 \& reprint 1966). The United States antidumping laws are directed at offsetting the competitive advantage that accrues to parties engaged in dumping products in the United States. See J. PAtTISON, supra note $3, \S 1.02[1]$, at 1-3; see also infra notes 23-50 and accompanying text (describing the purpose, history, and operation of the antidumping laws).

${ }^{5}$ See 19 U.S.C. $\S \S 1303,1671-1671$ (1982 \& Supp. IV 1986). A countervailing duty is a special fee levied on imports that have benefited from government subsidies. The purpose of United States countervailing duty laws is to offset the competitive advantage that accrues to the producers and exporters of subsidized imports. See $1 \mathrm{P}$. Feller, U.S. Customs and International Trade Guide $§ 17.01$ (1987); see also infra notes 72-108 and accompanying text (describing purpose, history, and operation of the countervailing duty laws).

${ }^{6}$ See J. PatTison, supra note $3, \S 1.01$, at $1-2$. Other unfair trade relief measures include investigations into unfair methods of competition in import trade, see 19 U.S.C. §§ 1337-38 (1982 \& Supp. IV 1986), and retaliation against countries that impose unreasonable restrictions on the importation of United States goods and services, 19 U.S.C. $\$ 2411$ (1982 \& Supp. IV 1986). See GAO REPORT TO THE CoNGRESS, supra note 1 , at 6 .

" The term "nonmarket economy country" is used throughout this Comment to refer to countries with nonmarket, state-controlled, or centrally-planned economies. Many authors refer to these countries as NMEs, SCEs, or CPEs. The following countries are frequently singled out for special treatment as nonmarket economy countries under the United States trade laws: Albania, Bulgaria, Czechoslovakia, German Democratic Republic, Hungary, People's Republic of China, Poland, Romania, and the Union of Soviet Socialist Republics. See GAO REPORT TO THE Congress, supra note 1 , at 1. Yugoslavia, because of the unique features of its economy, is not universally recognized as a nonmarket economy country. See id. 
market economies. ${ }^{8}$ Some commentators believe constructed values and surrogate countries can be used to determine the fair value of goods produced in nonmarket economy countries. ${ }^{9}$ Others question the viability of comparing dissimilar economies. ${ }^{10}$

Congress did not enact specific legislation to facilitate implementation of the countervailing duty laws against nonmarket economy countries. This inaction left open whether, and how, the laws were to be applied against nonmarket economy countries. In 1986, the Court of Appeals for the Federal Circuit reached its own conclusion in Georgetown Steel Corp. v. United States, ${ }^{11}$ holding that a countervailable subsidy cannot be found in a nonmarket economy..$^{12}$ Consequently, the court upheld a determination by the Department of Commerce that, while nonmarket economy countries are not specifically exempt from these laws, the impossibility of identifying and quantifying subsidies in their economies renders the laws inapplicable. ${ }^{\mathbf{1 3}}$

This result is not universally approved. Some critics argue that the surrogate-country procedures employed in antidumping investigations can also be applied to countervailing duty investigations against nonmarket economy countries. ${ }^{14}$ Others argue that surrogate-country

8 See Trade Act of 1974, Pub. L. No. 93-618, tit. III, § 321(d), 88 Stat. 1978, 2046-48 (1975) (codified at 19 U.S.C. $\S 1677$ b(c) (1982)); 19 C.F.R. $\S 358.8$ (1987) (regulations implementing this approach); see infra notes 51-71 and accompanying text (discussing the surrogate-country and constructed value methods).

'See, e.g., Comment, Dumping by State-Controlled-Economy Countries: The Polish Golf Cart Case and the New Treasury Regulations, 128 U. PA. L. REv. 217, 230 43 (1979) (discussing the Treasury regulations on constructed value and surrogatecountry methods and concluding that these approaches are a significant improvement over past enforcement efforts).

${ }_{10}$ See, e.g., Alford, When Is China Paraguay? An Examination of the Application of the Antidumping and Countervailing Duty Laws of the United States to China and Other "Nonmarket Economy" Nations, 61 S. CAL. L. Rev. 79, 98-127 (1987) (criticizing surrogate country procedures as an inadequate attempt to overcome the impossibility of comparing dissimilar economies); Soltysinski, Price Competition Between Free-Market and State-Controlled Economy Enterprises: The Legacy of the OMC v. Pezetel Litigations, 24 SwiSs Rev. INT'L CoMpeTITION L. 5, 20-23 (1985) [hereinafter Soltysinski, Price Competition] (discussing specific problems that arise in the direct application of free-market economy concepts to nonmarket economy countries); S. Soltysinski, The U.S. Import Relief Laws and Trade With Centrally Planned Economies 27-30 (forthcoming 3 FLA. INT'L L.J. (1988)) [hereinafter S. Soltysinski, U.S. Import Relief Laws] (same) (on file with the University of Pennsylvania Law Review).

11801 F.2d 1308 (Fed. Cir. 1986).

12 See id. at 1315. The court also concluded that Congress did not intend that the countervailing duty laws be applied against these countries. See id. at 1316-18.

${ }^{13}$ See id. at 1309.

14 See, e.g., Ehrenhaft, The Treasury's Proposed Approach to Imports from StateControlled Economy Countries and State-Owned Enterprises Under the Antidumping and Countervailing Duty Laws, in InTerface One: Conference Proceedings on the ApPlication of U.S. AnTIDUmping and Countervailing Duty Laws to IMPORTS FROM STATE-CONTROLled ECONOMIES AND STATE-OWNEd ENTERPRISES 
procedures are unfair and inadequate methods for determining whether a nonmarket economy country is engaged in an unfair trading practice. ${ }^{15}$ Recently, some members of Congress found the former group of commentators more persuasive. In 1987, legislation was introduced in both the House and the Senate to overturn Georgetown Steel and apply countervailing duty laws against nonmarket economy countries. ${ }^{16}$

Proposals to apply the countervailing duty laws against nonmarket economy countries raise two important issues: 1) is it technically possible to implement the countervailing duty laws against nonmarket economy countries; and 2) is the application of countervailing duty laws to these countries consistent with the goals of United States trade policy? This Comment refers to these issues throughout as problems of implementation and policy. The implementation problem was the focus of

80-81 (D. Wallace, G. Spina, R. Rawson \& B. McGill eds. 1980) [hereinafter INTERFACE ONE] (Deputy Assistant Secretary and Special Council, Dep't of Treasury, discussing proposed Treasury regulations to use surrogate-country method for estimating subsidies in nonmarket economy countries); Note, The Applicability of the United States Countervailing Duty Law to Imports from Nonmarket Economy Countries, 9 FORDHAM INT'L L.J. 596, 628-33 (1986) (proposing use of surrogate-country methods and calling for legislative reversal of Georgetown Steel); Comment, Georgetown Steel Corp. v. United States: Applying the Countervailing Duty Law to Imports from Nonmarket Economy Countries, 18 LAw \& POL'y INT'L Bus. 313, 329-36 \& 338 (1986) (suggesting the valuation of subsidies under the surrogate-country and simulated-constructed value approaches and calling for legislative reversal of Georgetown Steel); $c f$. Continental Steel Corp. v. United States, 614 F. Supp. 548, 555 (Ct. Int'l Trade 1985) (noting that the absence of a fair market value "did not deter the enforcing agency from developing the 'fair' home market value by reference to surrogate countries with market economies"), rev'd sub. nom. Georgetown Steel Corp. v. United States, 801 F.2d 1308 (Fed. Cir. 1986).

15 See, e.g., Alford, supra note 10, at 81-84 (criticizing the notion that nations are economically interchangeable); Corr, The NME Import Regulation Dilemma: Two Proposals for a New Regulatory Approach, 12 N.C.J. INT'L L. \& CoM. REg. 59, 6670 (1987) (criticizing surrogate-country and constructed value methodologies); Knoll, United States Antidumping Law: The Case for Reconsideration, 22 TEx. INT'L L.J. 265, 279-80 (1987) (criticizing constructed value test); Soltysinski, Price Competition, supra note 10 , at $8-14$ (discussing the unfairness of surrogate-country procedures as illustrated by the Polish Golf Cart litigation); Note, supra note 1, at $427-30$ (discussing analytical and administrative objections to the use of surrogate-country approaches to identifying and quantifying subsidies); Comment, Countervailing Duties and Alternative Trade Remedies for Imports from Nonmarket Economies, 27 VA. J. INT'L L. 699, 721-22 (1987) (determinations under surrogate procedure "have led to unpredictable results and could cause abuse"); Recent Development, Countervailing Duties and Non-Market Economies: The Case of the People's Republic of China, 10 Syracuse J. INT'L L. \& CompetrTION 405, 418-20 (1983) (rejecting the application of countervailing duty laws against nonmarket economy as an ethnocentric value judgment).

${ }_{16}$ See, e.g., Trade and International Economic Policy Reform Act of 1987, H.R. 3, § 157, 100th Cong. 1st Sess. (1987) [hereinafter 1987 Trade Bill] (applying the countervailing duty laws to nonmarket economy countries to the extent that a subsidy can be identified and quantified by the administering authority); H.R. 1687, 100th Cong. 1st Sess. (1987) (applying the countervailing duty laws to nonmarket economy countries); S. 770, 100th Cong. 1st Sess. (1987) (same). 
the Georgetown Steel case, and has since been addressed in a plethora of law review articles, notes, and comments. ${ }^{17}$ These writings explore the practical difficulties inherent in applying laws based on free-market principles to countries with economies that expressly reject those principles. Despite the amount of authoritative commentary on this problem, no consensus has been reached..$^{18}$ The policy problem, however, has not been examined as thoroughly. ${ }^{19}$ The current literature leaves unexplored the issue of whether the application of countervailing duty laws to nonmarket economy countries would advance the efficiency goals of the unfair trade practice laws.

This Comment addresses both the implementation and policy problems. It is not the intention of this Comment to add to the already voluminous literature discussing the difficulty of identifying and quantifying subsidies in nonmarket economy countries. Rather, it reviews this literature briefly to argue that applying countervailing duty laws to nonmarket economy countries is possible only at the cost of sacrificing accuracy in implementation. ${ }^{20}$ Consequently, the magnitude of the im-

17 See, e.g., Alford, supra note 10, at 89-95 (discussing technical problems of implementing the countervailing duty laws against nonmarket economy countries); Horlick \& Shuman, Nonmarket Economy Trade and U.S. Antidumping/Countervailing Duty Laws, 18 INT'L LAw. 807, 828-30 (1984) (same); Note, supra note 14, at 621-25 (evaluating the implementation problem); Comment, supra note 14, at 327-36 (discussing alternative methods of identifying and quantifying subsidies in nonmarket economy countries); S. Soltysinski, U.S. Import Relief Laws, supra note 10, at 2-10 (discussing technical problems of implementing the countervailing duty laws against nonmarket economy countries).

18 See Horlick \& Shuman, supra note 17, at 828-30 (noting divergent views on the question of whether subsidies in nonmarket economies are quantifiable). Compare Continental Steel, 614 F. Supp. at 554-55 (concluding that the Department of Commerce has sufficient expertise to overcome the problems of measuring subsidies in nonmarket economy countries) and Note, supra note 14, at 601, 628-33 (arguing that the countervailing duty law should apply to nonmarket economy countries and suggesting approaches) and Comment, supra note 14, at 327-33 (presenting alternative approaches to valuing subsidies under the countervailing duty law) with Barceló, supra note 1 , at 850 (stating that market imperfections and nondistortive actions have no meaning in a nonmarket economy) and Note, supra note 1, at 408-09 (stating that the theoretical and practical difficulties inherent in measuring subsidies in nonmarket economies argue for resorting to alternative measures) and Recent Development, supra note 15 , at $418-20$ (criticizing the imposition of market-based norms on nonmarket economy countries).

19 Only a few authors have addressed the policy aspect of applying countervailing duty laws to nonmarket economy countries. See Alford, supra note 10, at 127-30 (recognizing a need to move beyond the basic market/nonmarket distinction that undergirds our present antidumping law); Tarullo, supra note 1, at 555-56 (concluding that the administration of countervailing duty laws may be "connected more closely to implicit views of 'proper' governmental economic functions than to the efficiency aims upon which a market paradigm is based"); Recent Development, supra note 15, at 418-20 (regarding application of countervailing duty laws to the People's Republic of China.)

20 The application of countervailing duty laws to goods from nonmarket economy 
plementation problem is simply a matter of the level of inaccuracy Congress is willing to tolerate in order to impose free-market principles on nonmarket economy countries. ${ }^{21}$

The policy problem, on the other hand, is less subjective. This Comment contends that the economic principles underlying the unfair trade practice laws militate against the application of countervailing duty laws to nonmarket economy countries. It proposes that because subsidization and dumping are virtually indistinguishable in nonmarket economies, it would be irrational for Congress to apply both laws to nonmarket economy countries. Parallel application of these laws would go beyond offsetting the unfair trade practices of nonmarket economy countries, resulting in the exaggerated protection of United States producers. Consequently, the application of countervailing duty laws to nonmarket economy countries would violate the free-trade efficiency goals of United States trade laws. ${ }^{22}$

To reach these conclusions, this Comment examines the application of both the antidumping and the countervailing duty laws against nonmarket economy countries. Part I briefly reviews the purpose, history, and operation of the antidumping law. Part II examines similar aspects of the countervailing duty laws. Part III analyzes the implementation and policy problems involved in applying the countervailing duty laws to nonmarket economy countries. The Comment concludes that efforts to apply the countervailing duty laws to nonmarket economy countries are misguided and should be abandoned.

\section{An Overview of United States Antidumping Law}

The purpose of the antidumping law is to offset the competitive advantage enjoyed by foreign manufacturers over United States produc-

countries would produce inaccuracies analogous to those currently experienced under the antidumping law. Through the use of surrogate-country procedures, the Department of Commerce would find itself hypothesizing the existence and value of alleged subsidies. See infra notes 58-71 and accompanying text (describing the inaccuracies inherent in the use of surrogate-country and constructed value methods). The focal point of the implementation debate, therefore, should not be whether the law can be applied to nonmarket economy countries, but rather whether the decrease in accuracy that would accompany application is acceptable. But see Horlick \& Shuman, supra note 17 , at 829 (asserting that opposing views on the implementation problem focus on the definition of the term "subsidy").

${ }^{21}$ Congress has already demonstrated its willingness to accept some imperfection in the application of unfair trade practice laws to nonmarket economy countries. Methods currently employed in the discovery and quantification of dumping are inherently inaccurate: they find an offense and calculate its magnitude by analogy rather than through the alleged offender's actual cost and price data. See infra notes 58-71 and accompanying text.

${ }^{22}$ See supra notes 1-6 and accompanying text. 
ers as a result of unfair pricing schemes. ${ }^{23}$ Dumping is a form of international price discrimination whereby products are sold at different prices in different markets. ${ }^{24}$ In a "prototype dumping case," a producer sells its goods abroad at a price lower than the prevailing home market price. ${ }^{28}$ The difference between the product's price in the export market and its fair value ${ }^{26}$ is called the "margin of dumping." the United States antidumping law, a duty equal to the margin of dumping is imposed on imports sold at a price less than their fair value. $^{28}$ By exactly offsetting the margin of dumping, the law eliminates the producer's advantage, thus enforcing the goal of free-market efficiency.

\section{A. The History of Antidumping Law}

Congress enacted the first antidumping law in 1916, providing a civil cause of action for treble damages and criminal proceedings against parties dumping foreign merchandise in the United States. ${ }^{29}$ The statute requires the plaintiff to demonstrate the defendant's intent to destroy, injure, or prevent the establishment of an industry in the United States, or to restrain or monopolize trade and commerce in the product in question..$^{30}$ Because of the difficulties in demonstrating intent, few actions were filed under this law. ${ }^{31}$

Five years later, Congress enacted the Antidumping Act of 1921, ${ }^{32}$ a more potent law establishing a framework under which the Secretary of the Treasury would initiate and investigate allegations of dumping by foreign producers. ${ }^{33}$ The Antidumping Act of 1921 was broader in

${ }^{23}$ See J. PATtison, supra note $3, \S 1.02[1]$, at 1-3. For a discussion of the advantage that accrues to firms engaged in dumping, see Fisher, The Antidumping Law of the United States: A Legal and Economic Analysis, 5 LAW \& PoL'y INT'L BUS. 85, 87-89 (1973).

24 See Fisher, supra note 23, at 86-87; see also supra note 4 (defining dumping). at 87 .

${ }^{25}$ See J. PatTison, supra note $3, \S 1.02[1]$ at $1-3$ to 1-4; Fisher, supra note 23,

${ }^{26}$ The "fair value" of a product is generally considered to be the price of the commodity in the country where it is produced. See J. Pattison, supra note 3, $\S 1.02[1]$, at 1-4 n.2. Thus, "dumping" occurs when the product is sold in a foreign market at a price that is less than the product's fair value. See id.

27 See J. BARTON \& B. Fisher, InTERnational Trade AND Investment 288-

90 (1986); J. PATTison, supra note 3, § 1.02[1], at 1-4 n.2.

${ }^{28}$ See J. PatTison, supra note $3, \S 1.02[1]$, at 1-4 n.2.

29 See Act of Sept. 8, 1916, ch. 463, § 801, 39 Stat. 756, 798 (codified at 15

U.S.C. $\S 72$ (1982)).

so See id.

31 See J. Patrison, supra note $3, \S 1.03[1]$, at 1-7 to 1-8.

32 Act of May 27, 1921, ch. 14, 42 Stat. 11, repealed and superceded by Trade Agreements Act of 1979, Pub. L. No. 96-39, 93 Stat. 144.

s3 See Comment, Technical Analysis of the Antidumping Agreement and the 
scope than its predecessor; its coverage was not restricted to predatory dumping and therefore it was much easier to trigger. ${ }^{34}$ The Act remained substantially unamended until enactment of the Trade Agreements Act of $1979 .^{35}$

The Trade Agreements Act of 1979 modified the antidumping laws to bring them into conformity with the antidumping agreements reached at the Tokyo Round Multilateral Trade Negotiations. ${ }^{36}$ In the Trade and Tariff Act of 1984, ${ }^{37}$ Congress enacted procedural amendments to the antidumping law, to alleviate the Department of Commerce's ${ }^{\mathbf{3 8}}$ heavy workload in this area. ${ }^{\mathbf{3 9}}$

Trade Agreements Act, 11 LAw \& PoL'y INT'L Bus. 1405, 1409 (1979).

34 See id.

35 Pub. L. No. 96-39, 93 Stat. 144 (1979). Minor changes were made by the Trade Act of 1974, Pub. L. No. 93-618, § 321(d), 88 Stat. 1978, 2046-48 (1975), in which Congress amended the law to facilitate application to nonmarket economy countries. See infra notes 57-71 and accompanying text (discussing surrogate country and constructed value methods); see also Comment, supra note 9, at 224-27 (discussing section 205(c) of the Trade Act of 1974, which enacts the Treasury's third-country price test).

Antidumping laws were also addressed in the General Agreement on Tariffs and Trade, October 30, 1947, 61 Stat. A3, T.I.A.S. No. 1700, 55 U.N.T.S. 187 (entered into force Jan. 1, 1948) [hereinafter GATT]. The GATT was the first significant postWorld War II multilateral trade agreement. It sets nonbinding standards and rules of nondiscrimination in trade between signatory nations. The United States law was excused from consistency from the GATT because of the "grandfather clause" in the Protocol of Provisional Application. See J. Jackson, World Trade and the Law oF GATT § 30.1, at 770-71 (1969).

${ }^{36}$ See Agreement of Interpretation and Application of Article VI of the GATT, April 12, 1979, 31 U.S.T. 4919, T.I.A.S. No. 9650, GATT BISD 26th Supp. 171 (1980) (entered into force Jan. 1, 1980) [hereinafter Antidumping Code].

The Tokyo Round Multilateral Trade Negotiations was one of a series of mul:tination discussions on issues in international trade. Generally, the countries participating in these discussions are signatories to the GATT. However, a significant number of non-GATT countries participated in the Tokyo Round.

The previous round of negotiations, the Kennedy Round, was directed at lowering import tariffs. See L. Glick, Multilateral Trade Negotiations: World Trade AFTER THE TOKYo Round 5-7 (1984). The Tokyo Round negotiations, however, were directed at the reduction of nontariff barriers. See id. at 9-11. Many nonmarket economy countries participated in the Tokyo Round, including GATT signatories (Czechoslovakia, Poland, Romania, Cuba, and Yugoslavia) and non-GATT countries (Bulgaria and Vietnam). See id. at 3.

${ }^{37}$ Pub. L. No. 98-573, tit. VI, 98 Stat. 2948, $3024-43$ (codified in scattered sections of 19 U.S.C.).

${ }^{38}$ Responsibility for implementing the antidumping law was initially vested in the Treasury Department. That responsibility was transferred to the Secretary of Commerce in 1980 under President Carter's Reorganization Plan No. 3 of 1979, see 44 Fed. Reg. 69,273, 69,274 (1979), implemented by Exec. Order No. 12,175, 3 C.F.R. § 463 (1980).

39 See S. Lande \& C. VanGrasstek, The Trade and Tariff Act of 1984: Trade Policy in the Reagan Administration 107 (1986). 


\section{B. Elements of Antidumping Investigations}

There are two basic elements of an antidumping investigation: a determination by the United States International Trade Commission (ITC) that an import causes or threatens to cause material injury to a domestic industry and a determination by the International Trade Administration (ITA) of the Department of Commerce that "a class or kind of foreign merchandise is being, or is likely to be, sold in the United States at less than its fair value . . . ."40 If material injury is not shown, then no antidumping duty may be imposed, regardless of whether the ITA determines that goods are being sold at less than fair value. ${ }^{41}$ If both investigations result in affirmative determinations, the ITA imposes a duty on the product in an amount equal to the margin of dumping. ${ }^{42}$

To determine whether a product is being dumped, the ITA compares the product's fair value-also referred to as "foreign market value"43 — with the product's United States sales price. ${ }^{44}$ Congress has specified a number of alternative methods for calculating a product's fair value. ${ }^{45}$ The most preferred of these methods uses the price of the product in its home market. ${ }^{46}$ If the ITA is unable to identify a reliable price through home market sales, it will then look to the price at which the product is sold in third countries other than the United States. ${ }^{47}$

The ITA is sometimes unable to determine a product's fair value even after considering the product's home market price and its price in third country markets. In these cases, the ITA turns to the "constructed value" of the product. ${ }^{48}$ A product's constructed value is the cost of materials, fabrication, general expenses, and profit. ${ }^{49}$ After determining a product's fair value either through the home market, foreign market, or constructed value methods, the ITA compares that value with the

419 U.S.C. $\$ 1673$ (1982). These determinations take place simultaneously. See E. Rossides, U.S. Import Trade Regulation 197 (1986).

11 See 1 P. Feller, supra note 5, \& 18.06[1].

12 See J. PatTison, supra note $3, \S 1.03[2]$, at 1-10.

13 See 19 C.F.R. § 353.1 (1987).

44 See E. Rossides, supra note 40, at 198.

15 See 19 U.S.C. § 1677b (1982 \& Supp. IV 1986); House Comm. on Ways and Means, 100th Cong., 1s' Sess., Overview and Compilation of U.S. Trade Statutes 41-42 (Comm. Print 1987) [hereinafter Overview of U.S. Trade STATUTES].

${ }^{48}$ See 19 U.S.C. $\S 1677 b(a)(1)(A)$ (1982 \& Supp. IV 1986).

17 See 19 U.S.C. \& $1677 \mathrm{~b}(\mathrm{a})(1)(\mathrm{B})(1982)$.

48 See id. § $1677 \mathrm{~b}(\mathrm{a})(2)$.

48 See 19 C.F.R. $\S 353.8(\mathrm{a})(2) ; 1$ P. FELLER, supra note 5, § 18.03[3]; see also 19 U.S.C. $\S 1677 b$ (e) (1982 \& Supp. IV 1986) (setting out factors to be considered in calculating a product's constructed value). 
product's United States price. ${ }^{50}$ The difference between the two is the margin of dumping and the amount of the antidumping duty.

\section{The Application of Antidumping Laws to Nonmarket Economy Countries}

When enacting the current United States antidumping law, Congress realized that difficulties would occur when calculating the fair value of products produced in nonmarket economy countries. ${ }^{\mathbf{5 1}}$ Accordingly, both antidumping law and the Commerce Department's implementing regulations establish special methods for calculating the fair value of imports from nonmarket economy countries. ${ }^{52}$ Under these methods, the ITA simulates what the nonmarket economy producer's production costs and prices would be if the producer were operating in a comparable "surrogate" free-market economy country. ${ }^{53}$

These methods, in the order of preference established by the Department of Commerce, are 1) the home market price of a similar product produced in the surrogate country; ${ }^{54}$ ) the export price of the surrogate country's similar product; ${ }^{.5} 3$ ) the constructed value of a surrogate producer's product; ${ }^{56}$ and 4 ) the value of the nonmarket economy producer's product simulated through a calculation of the market value of the nonmarket economy producer's production function. ${ }^{57}$ These methods, however, have not eliminated the problem of valuing these imports from nonmarket economy countries. ${ }^{58}$

so See Overview of U.S. Trade Statutes, supra note 45 , at 41.

s1 See S. Rep. No. 1298, 93d Cong., 2d Sess. 174, reprinted in 1974 U.S. Code Cong. \& ADMIN. News 7186, 7311.

B2 See 19 U.S.C. § 1677b(c) (1982); 19 C.F.R. § 353.8 (1987).

ss See GAO RePoRt TO THE Congress, supra note 1, at 12-13. A surrogate country is one with a market economy that is "at a stage of economic development comparable to the state-controlled-economy ... . from which the merchandise is exported." 19 C.F.R. $\$ 353.8(b)(1)$ (1987). If no such country exists, another non-statecontrolled-economy country will be used as a surrogate, with prices adjusted for known differences in material and labor costs. See id. $\S 353.8(b)(2)$.

s4 See 19 G.F.R. § 353.8(a)(1) (1987). The surrogate-country's home market price is the price at which the similar merchandise is sold or offered for sale in the country. See id.

${ }^{s}$ See id. The export price is the price at which the similar merchandise is sold or offered for sale by the surrogate country to third countries other than the United States at the time of exportation. See id. $\S 353.5$ (a).

${ }^{\text {so }}$ See $i d$. $\S 353.8(\mathrm{a})(2)$. The constructed value of a product is the sum of the cost of materials, cost of production, an estimate of general expenses, and the usual industry profit. See id. § 353.6(a).

${ }_{57}$ See id. $\$ 353.8(\mathrm{c})$. Production costs used in the calculation include hours of labor required, raw materials expended, and amounts of energy consumed. A reasonable amount for general expenses and profit is added to the market value of the production function to obtain the final constructed value of the merchandise. See id.

s8 Cf. GAO REPORT TO THE CONGRESS, supra note 1, at 16-26 (outlining sug- 
The main problems faced when applying the special methods for calculating dumping margins by nonmarket economy producers revolve around the accuracy of surrogate-country comparisons. The outcome of an antidumping proceeding involving the use of a surrogate country depends heavily upon the choice of the surrogate. ${ }^{59}$ The current regulations, however, offer the ITA minimal guidance in choosing a surrogate country with a market economy at a comparable stage of development. ${ }^{\text {,0 }}$

Even if a proper surrogate country is found, the subsequent price comparison cannot determine conclusively whether the nonmarket economy producer is engaged in dumping. The most that these approaches can possibly reveal is a price differential between the product's United States sales price and the price of a similar product in the surrogate country. The differential, or lack thereof, can be caused by a variety of factors unrelated to dumping. The nonmarket economy producer may enjoy a "real" competitive advantage resulting from an economy of scale; ${ }^{61}$ the choice of surrogate country may have been misguided; ${ }^{62}$ or the surrogate country may be subsidizing its producers. ${ }^{63}$

Under the surrogate-country approaches, the ITA also encounters problems in gathering information from both the nonmarket economy producer and the surrogate-country government and producers. ${ }^{64}$ The surrogate-country producer may refuse to provide information out of fear that it will subject itself to a future antidumping investigation. ${ }^{\mathrm{Bs}}$ The nonmarket economy country also will often refuse to provide information necessary to the investigation. ${ }^{68}$

The surrogate constructed value approach only requires confiden-

gested improvements in the use and administration of these special nonmarket economy country methods).

${ }^{58}$ See Note, supra note 1 , at 427-30.

${ }^{60}$ See 19 C.F.R. \& 353.8(b) (1987) ("Comparability of economic development shall be determined from generally recognized criteria, including per capita gross national product and infrastructure development (particularly in the industry producing such or similar merchandise).") The problems created under this vague standard of comparability are discussed in Horlick \& Shuman, supra note 17, at 820-21.

${ }^{81} \mathrm{Cf}$. Note, supra note 1 , at 429 (noting that the surrogate-producer method "does not allow the nonmarket producer to demonstrate that its processes utilize some economic efficiency that results in its lower export prices").

${ }^{62}$ See Comment, supra note 14, at 330-31; Note, supra note 1, at 427-28.

63 See Note, supra note 1 , at 428.

64 See Horlick \& Shuman, supra note 17, at 821-22.

${ }^{60}$ See S. Soltysinski, U.S. Import Relief Laws, supra note 10, at 9. The surrogate-country government may also withhold information out of fear that it will expose itself to a future countervailing duty investigation. See $i d$.

${ }^{68}$ See GAO REPORT TO THE CoNGRESS, supra note 1, at 2 ("[I]n many of these countries, divulging government or enterprise operating data is a violation of domestic law."). 
tial information from the nonmarket economy producer. ${ }^{67}$ This approach, however, requires the ITA to account for known price differentials between the surrogate and nonmarket economy countries. Such an accounting would require a cost comparison of materials and labor between the two countries ${ }^{68}$ - which in turn requires reliance upon prices that are economically meaningless in the nonmarket economy country. ${ }^{69}$ Even if these prices could be determined, the imprecision of nonmarket economy exchange rates prevents the conversion of prices to a meaningful dollar value. ${ }^{70}$

Despite the problems with the surrogate-country approaches to quantifying dumping margins in nonmarket economy countries, there is no legislative movement to discontinue application of the antidumping law to nonmarket economy countries. This law represents Congress's belief that it is necessary to offset dumping by nonmarket economy producers, even if the best method for doing so is laden with inaccuracies. ${ }^{71}$

\section{An Overview of United States Countervailing Duty LAWS}

The purpose of United States countervailing duty laws is to offset the unfair competitive advantage that foreign manufacturers enjoy over domestic producers as a result of subsidies granted by foreign governments to their industries. ${ }^{72}$ The principle behind these laws is that United States producers should not have to compete with foreign firms that are not subject to the same competitive market constraints. ${ }^{73}$ An important distinction between antidumping and countervailing duty laws is that the former aim to offset unfair trade practices initiated by private foreign enterprises, while the latter aim to offset unfair trade practices initiated by foreign governments. ${ }^{74}$ Under United States coun-

6z Seè Note, supra note 14 , at 631 .

${ }^{8}$ See id.

Bg See Horlick \& Shuman, supra note 17, at 818.

${ }^{70}$ See Zerby, Ellsworth \& Schmitt, Dumping of Non-Factor Services: Some Implications of Recent Experiences with Controlled-Economy Shipping, 4 Nw. J. INT'L. L. \& Bus. 37, 45 (1982) (noting that the exchange rate is also state-controlled "so that it may not be an appropriate numeraire for converting these costs into [dollars]").

7 See GAO RePORT To THE CongRess, supra note 1, at 12-25 (recommending amendment, not abolition, of the surrogate-country methods, despite recognition that the methods produce results that are "highly unpredictable and of limited economic validity").

72 See Overview of U.S. Trade Statutes, supra note 45, at 40.

73 See GAO Report to the Congress, supra note 1, at 6.

74 See J. BARTon \& B. Fisher, supra note 27, at 281 ("[I]t is usually a firm that dumps but a government that subsidizes . . . ."); see also Denton, The Non-Market Economy Rules of the European Community's Anti-Dumping and Countervailing Duties Legislation, 36 INT'L \& CoMP. L.Q. 198, 236 (1987) ("In a free-market situation 
tervailing duty law, the duty is equal to the countervailable subsidy, ${ }^{75}$ thereby enforcing the goal of free-market efficiency.

\section{A. The History of Countervailing Duty Law}

Gongress enacted this nation's first countervailing duty law in $1890 .^{76}$ This law required the imposition of an additional duty on sugar imported from countries paying "directly or indirectly, a bounty on the exportation" of certain grades of sugar. ${ }^{77}$ Seven years later, in the Tariff Act of 1897, Congress passed a more general countervailing duty law. ${ }^{78}$ The 1897 Act substantially broadened the scope of countervailable imports by covering any dutiable merchandise that received a bounty or grant paid directly or indirectly on exportation. ${ }^{79}$ In order to provide relief from such imports, the Act required that a countervailing duty, equal to the net amount of the subsidy, be imposed on the import. ${ }^{80}$

The Tariff Acts of $1913^{81}$ and $1922^{82}$ further expanded countervailing duty law..$^{83}$ Section 303 of the Tariff Act of 1930 offered a small change in administrative procedure but was otherwise identical in substance and language to the 1922 law. ${ }^{84}$ In the Trade Act of 1974, Congress amended section 303, expanding the scope of the law to cover any

.. . dumping is in the private domain and subsidies are in the public domain."). But see Fisher, Dumping: Confronting the Paradox of Internal Weakness and External Challenge, 1 Mich. Y.B. INT'L LEGal STud. 11, 12 (1979) (asserting that dumping practices are increasingly state-led policy efforts).

75 See J. Patrison, supra note 3, § 1.04, at 1-13.

78 See Tariff Act of 1890 , ch. 1244, $\S 237,26$ Stat. 567, 584 (McKinley Tariff).

77 See id. Grants paid on a product's exportation are called "export subsidies."

See J. JACKSON, supra note $35, \S \cdot 15.1$, at 355-56. Congress reenacted this provision in 1894 , applying it to all sugar imports, and introduced the concept of the net subsidy. See Tariff Act of 1894 , ch. 349, \& 182.5, 28 Stat. 509, 521.

${ }^{78}$ See Tariff Act of 1897, ch. 11, § 5, 30 Stat. 151, 205 (Dingley Tariff).

${ }^{79}$ See id. The Act also expanded the coverage of the 1894 Act to include subsidies provided by any country, dependency, or colony. See id.

so See id.

81 Tariff Act of 1913, ch. 16, 38 Stat. 114 (Underwood Tariff Act).

${ }_{82}$ Tariff Act of 1922, ch. 356, 42 Stat. 858 (Fordney-McCumber Tariff Act).

${ }_{83}$ The Tariff Act of 1913 expanded countervailing duty law to include imports receiving a bounty or grant from a "province, or other political subdivision of government." Tariff Act of 1913 , ch. 16, § IV(E), 38 Stat. 114, 193. The Tariff Act of 1922 further broadened the scope of countervailable subsidies. It applied to bounties or grants bestowed by a "person, partnership, association, cartel, or corporation" and covered products benefiting from domestic subsidies by including bounties "upon the manufacture or production" of articles. Tariff Act of 1922, ch. 356, $\S 303,42$ Stat. 858, 935-36.

84 See Tariff Act of 1930, ch. 497, $\S 303,46$ Stat. 590, 687 (codified as amended at 19 U.S.C. $\S 1303$ (1982)) (Smoot-Hawley Tariff) (varying from Tariff Act of 1922 only by requiring the Secretary of the Treasury to measure and declare each distinct subsidy applied to an imported item and not simply their sum). 
subsidized article or merchandise, regardless of whether it is a dutiable good. ${ }^{85}$ In addition, the Act required a determination of injury to a United States industry before imposing a countervailing duty on dutyfree imports, but only if such a test is required by international obligations. $^{86}$

In 1979, Congress enacted a second countervailing duty law by adding section 701 to the Tariff Act of $1930 .^{87}$ The central purpose of this amendment was to make the trade laws consistent with the requirements of the Subsidies Code, signed that year at the Tokyo Round Multilateral Trade Negotiations. ${ }^{88}$ The reforms promulgated by the Subsidies Code regarding countervailing duty laws are quite basic. The Subsidies Code, like the GATT, requires that countervailing duties not be imposed on an import until a material injury to an industry in the importing country is shown. ${ }^{\mathbf{8 9}}$ The Subsidies Code, however, further defines this standard of material injury, setting out explicit guidelines for determining when a material injury has been inflicted or is threatened. ${ }^{\text {so }}$

Congress implemented these commitments in section 701 rather than amending the existing language in section 303 because the requirements of the Subsidies Code are meant to apply only to countries that are signatories to the Subsidies Code or countries with whom the United States has negotiated substantially similar bilateral agree-

8s See Trade Act of 1974, Pub. L. No. 93-618, § 303(a)(1), 88 Stat. 1978, 2049 (1975) (codified as amended at 19 U.S.C. $\S 1303$ (1982)).

${ }_{\mathrm{BB}} \mathrm{See} i d$. $\$ 303(\mathrm{~b}), 88$ Stat. at 2049 . This provision undoubtedly refers to obligations arising under the GATT. Under the terms of the GATT, countervailing duties may be applied only in instances where the importing country determines that a subsidized import is causing or threatens to cause material injury to a domestic industry. See GATT, supra note 35, art. VI, I 5. The United States was not required to amend its laws to comply with the GATT because of a "grandfather clause" in the Protocol of Provisional Application that exempts previously existing legislation from compliance with GATT requirements. See supra note 35.

${ }_{87}$ See Trade Agreements Act of 1979 , Pub. L. No. 96-39, $\S \S 101,103,93$ Stat. $144,151,190$ (codified as amended at 19 U.S.C. $\$ 1671$ (1982)).

${ }^{88}$ See supra note 36 . The agreement concerning subsidies and countervailing duties negotiated at the Tokyo Round is the Agreement on Interpretation and Application of Articles VI, XVI, and XXIII of the General Agreement on Tariffs and Trade, April 12, 1979, 31 U.S.T. 513, T.I.A.S. No. 9619, GATT BISD, 26th Supp. 56 (1980) (entered into force Jan. 1 1980) [hereinafter Subsidies Code]. For a more comprehensive overview of the Tokyo Round and the resulting agreements, see generally $L$. Glick, supra note 36, and IMPLEMENTING THE TOKYo Round: NATIONAL ConstiTUtions and International Economic Rules (J. Jackson, J. Louis, \& M. Matsushita eds. 1984).

${ }_{89}$ See Subsidies Code, supra note 88 , art. 1, 31 U.S.T. at 519 , T.I.A.S. No. 9619 , at 2, GATT BISD, 26th Supp. at 57.(requiring continued signatory compliance with article VI of the GATT).

${ }_{90}$ See id. art. 6, 31 U.S.T. at 527-29, T.I.A.S. No. 9619, at 10-12, GATT BISD, 26th Supp. at 57. 
ments. $^{91}$ Consequently, the United States has two different countervailing duty laws-one that applies to countries that have signed the Subsidies Code or a similar agreement, and a second law that applies to all other countries. The only substantive difference between the two is that the former, section 701, requires the administering authority to make a determination of material injury before imposing countervailing duties, whereas the latter, section 303 , requires no showing of injury. ${ }^{\mathbf{9 2}}$ Currently, most nonmarket economy countries are not signatories to the Subsidies Code and therefore do not receive the benefit of an injury test. $^{93}$

Congress has not substantially altered the countervailing duty laws since 1979. Amendments embodied in the Trade and Tariff Act of $1984^{94}$ broadened the scope of the laws to cover upstream subsidies, ${ }^{95}$ but were otherwise limited to altering filing and processing requirements for petitions and investigations.

\section{B. Elements of Countervailing Duty Investigations}

There are three basic elements of a countervailing duty investigation: finding material injury to a domestic industry (when applicable), ${ }^{96}$ identifying the existence of a subsidy, and quantifying the net benefit conveyed by the subsidy. ${ }^{97}$

The ITC is responsible for investigating the first element, whether an industry has been materially injured, and whether the allegedly subsidized import is a cause of the injury. ${ }^{98}$ The ITC analyzes the volume

91 See Trade Agreements Act of 1979, Pub. L. No. 96-39, tit. I, § 101, 93 Stat. 151 ("TT]he term 'country under the Agreement' means a country . . . which has assumed obligations . . . under the Agreement . . . ."). For a further discussion of countries considered to be "countries under the agreement," see J. PATTISON, supra note 3, $\S 6.01[2]$.

${ }_{82}$ Compare 19 U.S.C. $\S 1303(a)(2)$ (1982) (no injury test required under $\S 303$ ) with 19 U.S.C. $\S 1671$ (a)(2) (1982) (injury test available under $\S 701$ ).

${ }^{83}$ See GAO REPORT TO THE CoNGRESS, supra note 1, at 29; see also infra note 163 (detailing major nonmarket economy countries' eligibility for injury test).

84 Pub. L. No. 98-573, tit. VI, 98 Stat. 2948, 3024-43 (codified in scattered sections of 19 U.S.C.)

95 An "upstream subsidy" is a benefit bestowed on an input used in the production of a good to be exported. See OVERview of U.S. Trade StatuTes, supra note 45 , at 50 .

${ }_{98}$ See 19 U.S.C. $\S 1303(\mathrm{a})(2)$ (1982); 19 U.S.C. $\S 1671(\mathrm{a})(2)$ (1982); OvERVIEW of U.S. Trade Statutes, supra note 45 , at 52 . This element is required only in investigations initiated under section 701 of the Tariff Act of 1930,19 U.S.C. $\S 1671$ (1982). See supra text accompanying notes 89-93.

97 See GAO REPORT TO THE CONGRESS, supra note 1, at 28.

${ }^{88}$ See Overview of U.S. Trade STatutes, supra note 45, at 52. See generally, Madden, The Threat of Material Injury Standard in Countervailing Duty Enforcements, 16 LAW \& POL'Y INT'L Bus. 373 (1984) (arguing that while the material 
of imports, their effect on United States prices, and their effect on United States producers, taking into account such factors as "lost sales, market share, profits, productivity, return on investment, and utilization of production capacity." in question are causing material injury to a domestic industry, the investigation is then turned over to the ITA. ${ }^{100}$

The ITA is responsible for the second and third elements of a countervailing duty investigation. Its dual task of identifying and quantifying alleged subsidies is frequently difficult. ${ }^{101}$ Part of this difficulty stems from the amorphous nature of the term "subsidy." Neither the GATT, the Subsidies Code, nor the United States countervailing duty laws define the term. The countervailing duty laws merely provide that the term means the same as the terms "bounty" and "grant" as used in section 303. ${ }^{102}$

Conventional definitions refer to a subsidy as a "grant of money from a government to a private enterprise." ${ }^{103}$ Some scholars, however, argue that subsidies are manifested in almost any government policy that benefits an industry. ${ }^{104}$ While the laws ostensibly cover subsidies granted by institutions other than governments, ${ }^{105}$ countervailing duties

injury prong of the analysis is the most opaque, the ITC, through its decisions, has given it constant and predictable meaning).

99 OVerview OF U.S. Trade STATUTES, supra note 45, at 52.

100 See 19 U.S.C. $\S 1671$ (a)(2) (1982 \& Supp. IV 1986). In 1980, enforcement responsibilities for the countervailing duty and antidumping laws were transferred from the Department of the Treasury to the Department of Commerce pursuant to President Carter's Reorganization Plan No. 3 of 1979. See 44 Fed. Reg. 69,273, 69,274 (1979), implemented by Exec. Order No. 12,175, 3 G.F.R. § 463 (1980).

101 See GAO RePORT TO THE Congress, supra note 1 , at 31.

102 See 19 U.S.C. $\S 1677(5)$ (1982); Overview OF U.S. Trade StatuTes, supra note 45 , at 51 . These laws also provide an illustrative list of subsidies that include the examples of export subsidies set out in the Subsidies Code. See 19 U.S.C. $\S 1677(5)(\mathrm{A})$ (1982) (defining the term "subsidy" to include "[a]ny export subsidy described in Annex A to the (Subsidies Code]").

103 Webster's Deluxe Unabridged Dictionary 1816 (2d ed. 1979); see also BLACK's LAW DICTIONARY 1280 (5th ed. 1979) ("[a] grant of money made by government"); The McGraw-Hill Dictionary of Modern Economics 446 (3d ed. 1983) ("[a] payment to individuals or business by a government for which it receives no products or services in return").

${ }_{104}$ See J. JACKSON, supra note 35, at 366 ("Indeed, almost anything that assists a business could be termed a subsidy . . . ."); Mundheim \& Ehrenhaft, What Is a "Subsidy"? A Discussion Paper, in Interface Three: Legal Treatment of Domestic Subsidies 95 (D. Wallace, F. Loftus \& V. Krikoriam eds. 1984) [hereinafter INTERFACE THREE] (discussing the status of government job training programs, relaxed environmental restrictions, depreciation rules, government purchases, and industry-specific research and development grants as domestic subsidies).

${ }^{105}$ See 19 U.S.C. $\S 1303(a)(1)(1982)$ (The Act applies "whenever any country, dependency, colony, province, or other political subdivision of government, person, partnership, association, cartel, or corporation, shall pay or bestow . . . any bounty or grant ...."). 
have never been imposed to offset subsidies granted by nongovernmental institutions. ${ }^{106}$

After identifying a government action as a subsidy, the ITA must quantify the net benefit the producer receives from that action. First, the ITA must calculate the gross value of the subsidy. From that value, the ITA subtracts any costs incurred in receiving the subsidy. ${ }^{107}$ The resulting figure is the net amount of the subsidy, and will be the amount of the countervailing duty imposed. ${ }^{108}$ Under this formula, the countervailing duty should exactly offset the unfair competitive advantage enjoyed by the subsidized exporter.

\section{The Application of Countervailing Duty Laws to Nonmarket Economy Countries}

Before the 1980s, no countervailing duty investigation was initiated against a product from a nonmarket economy country. ${ }^{109}$ In late September 1983, a group of United States textile manufacturers and unions ${ }^{110}$ filed a petition for the first such investigation, against imports from the People's Republic of China. ${ }^{111}$ The petition alleged that China's policy of granting a preferred monetary exchange and other benefits to the producers of exported goods-in this case, textiles, apparel, and related products-constituted a countervailable subsidy. ${ }^{\mathbf{1 1 2}}$ The investigation was never completed; in response to protests from the

106 The scope of the countervailing duty laws were administratively limited to subsidies provided by governments in Grain Oriented Silicon Electrical Steel from Italy, 42 Fed. Reg. 54,899 (Dep't Treas. 1977) (final determination), in which the Department of the Treasury based its negative finding on the inability of the petitioners to prove that the government provided the alleged subsidy. See also Verrill, State-Owned Enterprises and the Countervailing Duty Law: Where, Oh, Where, to Draw the Line, in INTERFACE. THREE, supra note 104, at 36 ("The law, as most recently amended, limits the definition of countervailable subsidies to those paid by the government or required by government actions.").

107 These costs might include application fees or deposits paid in order to receive the subsidy, any loss in the value of the subsidy resulting from government-mandated deferred receipt, and any duties or charges specifically intended to offset the subsidy. See Overview of U.S. Trade Statutrs, supra note 45, at 51; J. Pattison, supra note $3, \S 6.01[6]$.

${ }^{108}$ See 19 U.S.C. § 1303(a)(1) (1982 \& Supp. IV 1986) (requiring that the countervailing duty imposed be "equal to the net amount of such bounty or grant").

109 See GAO RePorT to THE Congress, supra note 1, at 27; Recent Development, supra note 15 , at 405 n.5.

${ }_{110}$ The petition was filed by the American Textiles Manufacturers Institute (ATMI), the Amalgamated Clothing and Textile Workers Union (ACTWU), and the International Ladies' Garment Workers Union (ILGWU). See Textiles, Apparel, and Related Products from the People's Republic of China, 48 Fed. Reg. 46,600 (Dep't Comm. 1983) (initiation) [hereinafter Textiles from China].

111 See Recent Development, supra note 15, at 405.

112 See Textiles from China, supra note 110 , at 46,600 . 
Chinese government, the Secretary of Commerce convinced the petitioners to withdraw their petition in return for a guarantee that the executive branch would work to resolve their concerns through other channels. ${ }^{113}$

A second countervailing duty petition was filed against a nonmarket economy country in November 1983, alleging that Poland and Czechoslovakia were subsidizing exports of carbon steel wire rod. $^{114}$ In its investigation, the Department of Commerce determined that countervailable subsidies cannot be identified in a nonmarket economy country. ${ }^{115}$ The Department concluded that the concept of subsidization has no meaning in an economy where costs, prices, and profits are determined by central planning rather than by market forces. ${ }^{\mathbf{1 1 6}}$ The carbon steel wire rod determinations subsequently led the Department to rescind a separate countervailing duty investigation into imports of potash (potassium chloride) from the German Democratic Republic $^{117}$ and the Soviet Union. ${ }^{118}$

The Department's nonmarket economy "exemption" is based on its view that the basic elements of a countervailing duty investigation-identification and quantification of the alleged subsidy ${ }^{119}$-are thwarted by the structure of a nonmarket economy. ${ }^{120}$ This "exemption" was overruled by the Court of International Trade ${ }^{\mathbf{1 2 1}}$ in Conti-

113 See Textile, Apparel, and Related Products from The People's Republic of China, 48 Fed. Reg. 55,492 (Dep't Comm. 1983) (termination); Industry, Commerce Agree to Delay Decision of Chinese Textiles CVD Case, 9 U.S. Import Weekly (BNA) No. 10, at 373 (Dec. 7, 1983); Recent Development, supra note 15, at $407 \mathrm{n} .14 \mathrm{a}$. The Administration altered procedures under section 406 of the Trade Act of 1974, 19 U.S.C. § 2436 (1982), allowing the President to invoke import relief against market disruption caused by imports from communist countries. See Recent Development, supra note 15 , at 407 n.14b.

114 See Carbon Steel Wire Rod From Czechoslovakia, 49 Fed. Reg. 19,370 (Dep't Comm. 1984) (final determination) [hereinafter Steel from Czechoslovakia]; Carbon Steel Wire Rod From Poland, 49 Fed. Reg. 19,374 (Dep't Comm. 1984) (final determination). Because these determinations are virtually identical, future citations are only to the Steel from Czechoslovakia determination.

115 See Steel from Czechoslovakia, supra note 114, at 19,371 ([W]e have concluded that bounties or grants . . . cannot be found in NME's").

${ }^{116}$ See Id. at 19,373.

117 See Potassium Chloride from the German Democratic Republic, 49 Fed. Reg. 23,428 (Dep't Comm. 1984) (rescission and dismissal).

118 See Potassium Chloride from the Soviet Union, 49 Fed. Reg. 23,428 (Dep't Comm. 1984) (rescission and dismissal).

119 See GAO REPORT TO THE CONGREss, supra note 1, at 28. In some countervailing duty cases, a showing of material injury to the affected industry is required. Few nonmarket economy countries receive the benefit of this test, however. See infra note 163 .

${ }^{120}$ See Steel from Czechoslovakia, supra note 114 , at 19,373.

121 The Court of International Trade has jurisdiction over final determinations issued by the Department of Commerce in antidumping and countervailing duty pro- 
nental Steel Corp. v. United States. ${ }^{122}$ In that case, the court concluded that subsidies can exist in nonmarket economies, and that the Commerce Department should somehow discover a method for identifying and quantifying them. ${ }^{123}$

The Court of International Trade sought to circumvent the problems of investigating alleged subsidies in nonmarket economy countries by broadly defining the concept of subsidization as "a distortion of a pattern of regularity or even a pattern of reasonably expected fairness."124 Under this definition, the court reasoned that the ITA can "detect patterns of regularity,"126 and identify as subsidies any "beneficial deviations from those patterns."

In Georgetown Steel Corp. v. United States, ${ }^{127}$ the Court of Appeals for the Federal Circuit reversed the holding of the Court of International Trade. The Court of Appeals adopted the arguments set out by the Commerce Department in its final determination ${ }^{128}$ and concluded that subsidization is a market phenomenon that by definition cannot exist in a nonmarket economy. ${ }^{129}$

\section{The Implementation and Policy Problems of ApPlying Countervailing Duty Laws to Nonmarket ECONOMY COUNTRIES}

In 1987, several bills were introduced in the House and Senate to invalidate Georgetown Steel Corp. v. United States ${ }^{130}$ and apply the countervailing duty laws against nonmarket economy countries. The most successful of these efforts was section 157 of the 1987 Trade Bill. This provision-introduced in the House and unopposed by the Senate-remained in the Bill until the final stages of the conference committee, ${ }^{131}$ suggesting that future legislative attempts to overturn

ceedings. See 19 U.S.C. $\S 1516 a(a)$ (1982 \& Supp. IV 1986). This jurisdiction is exclusive. See 28 U.S.C. § 1581(c) (1982).

122614 F. Supp. 548 (Ct. Int'l Trade 1985), rev'd sub. nom. Georgetown Steel Corp. v. United States, 801 F.2d 1308 (Fed. Cir. 1986).

${ }^{123}$ See id. at 554 ("[T]he Commerce Department has the authority and ability to detect patterns of regularity and investigate beneficial deviations from those patterns - and it must do so regardless of the form of the economy.").

124 Id.

${ }^{125} I d$.

${ }^{126}$ Id.; see also Horlick \& Shuman, supra note 17, at 829-30 (explaining the concept of defining subsidization as any government-sponsored preferential treatment).

127801 F.2d 1308 (Fed. Cir. 1986).

${ }^{128}$ See Note, supra note 14 , at 621.

129 See Georgetown Steel, 801 F.2d at 1315-16.

130801 F.2d 1308 (Fed. Cir. 1986).

131 The Senate, abandoning its own trade proposals, passed a bill laying out proposed amendments to H.R. 3. The Senate version did not address the issue of applying 
Georgetown Steel may prove successful.

In considering section 157, however, Congress seemingly ignored the policy implications and focused solely on implementation. ${ }^{\mathbf{1 3 2}}$ The Bill would have required the Department of Commerce to apply the law to nonmarket economy countries whenever a subsidy could reasonably be identified and measured. ${ }^{133}$ The House Report addressed only "the theoretical and administrative difficulties of applying the countervailing duty law"134 and made no mention of whether application of the law would be consistent with United States trade policy. Only the Reagan administration objected to section 157 on policy grounds. ${ }^{135}$

This Part examines the implementation and policy problems that arise with the application of countervailing duty laws to nonmarket economy countries. The contention is that the implementation problem fails to offer a dispositive argument either in favor of or in opposition to the application of countervailing duty laws to these countries. The implementation problem can be circumvented by the use of surrogatecountry methods, ${ }^{136}$ but only at the cost of accuracy in the application of the laws. Thus, to resolve the implementation problem, Congress must simply decide whether it is willing to sacrifice accuracy in return for applicability.

The solution to the policy problem, however, is not as subjective. In theory, application of the countervailing duty laws would duplicate

the countervailing duty laws to nonmarket economy countries, tacitly accepting the House proposal. See Omnibus Trade and Competitiveness Act of 1987, H.R. 3, 100th Cong., 1st Sess. (1987). The differences between these bills are laid out in STAFF of House Comm. on Ways and Means, 100th Cong., 1st Sess., H.R. 3, Omnibus Trade and Competitiveness Legislation: Comparison of the House and Senate Provisions 101 (Comm. Print 1987). Congress did not include $\S 157$ in the final version of the Trade Bill. See H. Conf. ReP. No. 576, 100th Cong., 2d Sess. reprinted in 134 CoNG. REC. H1863, H2042 (daily ed. Apr. 20, 1988) (conference report on H.R. 3, supra).

132 See supra notes 17-19 and accompanying text (defining the policy and implementation problems).

${ }^{133}$ See 1987 Trade Bill, supra note 16, § 157.

134 H. REP. No. 40, 100th Gong., 1st Sess. 138 (1987). Notably, the House failed to provide any guidance as to how the administering authority was to overcome these "difficulties."

${ }^{136}$ See Letter from James A. Baker, Secretary of the Treasury, C. William Verity, Secretary of Commerce, William Brock, Secretary of Labor, Clayton Yeutter, U.S. Trade Representative, and James Miller, Director, Office of Management and Budget, to The Honorable Dan Rostenkowski, Chairman, House Committee on Ways and Means 13-15 (Oct. 30, 1987) (on file at the University of Pennsylvania Law Review). While the Administration shared the general concern over the implementation problem, see id. at 15, it expressed specific concern that many of the various provisions relating to nonmarket economy countries would violate GATT commitments and expose United States producers to retaliatory measures. See id. at 13.

138 See supra note 14 and accompanying text. 
the protection already available through the antidumping law. This duplicative protection, combined with the fact that the countervailing duty laws would be enforced against most nonmarket economy countries without requiring any showing of injury, would result in excessive protection of United States producers and the impairment of important political and trade relations.

\section{A. The Implementation Problem}

The implementation problem inherent in applying countervailing duty laws to nonmarket economy countries is the difficulty in accurately identifying and quantifying subsidies in the absence of marketbased prices, costs, and exchange rates. The operation of a nonmarket economy is radically different from even the most government-driven market economy ${ }^{137}$ In a free-market economy, prices and resource-allocation are determined by the natural forces of supply, demand, and scarcity of commodities. ${ }^{138}$ In the absence of government intervention, these forces interact to allocate resources efficiently to their most valuable uses. Thus, a firm operating in a free-market economy purchases inputs and sells its output at market-determined prices. ${ }^{139}$

The fundamental distinction between market and nonmarket economies is that in the latter, the market is supplanted by state-controlled central planning. In a nonmarket economy, profits, prices, and resource allocation are controlled by the state and do not reflect the forces of supply, demand, or allocative efficiency. ${ }^{140}$ The price of a commodity is

${ }^{137} C f$. Soltysinski, Price Competition, supra note 10, at 6 ("[T]he frequency and scope of state intervention in the market is incomparably wider in the centrally planned economy countries [than in market economies]."). Some scholars question the logic of line-drawing between market and nonmarket economies. See Alford, supra note 10, at 98-127. Professor Tarullo goes even further, rejecting the market ideal embodied in United States trade laws as an impossible standard. See Tarullo, supra note 1, at 55760. Despite the fact that the United States has a mixed economy with both private and public economic control, and centrally-planned economies are experimenting with western economics, the two remain very different. Compare P. SAMUelson, supra note 1 , at 37-49 (describing the price functioning of our own "mixed economy") with id. at 819-24 (describing the Soviet, Chinese, and Eastern European economies).

138 See Steel from Czechoslovakia, supra note 114, at 19,371; P. Samuelson, supra note 1 , at 39-41.

${ }_{139}$ See Steel from Czechoslovakia, supra note 114, at 19,371; P. SAMuelson, supra note 1 , at $39-41$.

140 See GAO RePort to THE Congress, supra note 1, at 2; P. SAMUelson, supra note 1, at 821-23; Downey \& Graham, The Regulation of Dumping from StateControlled Economies: Where Next? in InTERface Two: Conference Proceedings on the Legal Framework of East-West Trade 435, 438-39 (D. Wallace \& D. Flores eds. 1982) (hereinafter INTERFACE Two]; see also Note, supra note 1, at 416 ("Production costs and sale prices reflect an entirely different set of factors than these figures would represent in a market economy."). 
but one of the policy tools used by the government to promote its social, political, and economic objectives. ${ }^{141}$ Prices used to determine profits need not reflect the actual costs of production, ${ }^{142}$ for the goal of microeconomic efficiency generally does not exist in a nonmarket economy. ${ }^{143}$ Furthermore, in most nonmarket economy countries there is no reliable exchange rate by which to convert the nonmarket currency into dollars. ${ }^{144}$

These factors operate to create an economy that, "[b]y market standards . . . is riddled with distortions." 145 In a nonmarket economy, the state and the producer are virtually the same. ${ }^{146}$ Consequently, an alleged act of subsidization is conceptually inseparable from the state's normal role of allocating resources. ${ }^{\mathbf{1 4 7}}$ These distortions led the Department of Commerce ${ }^{148}$ and many academics ${ }^{148}$ to the conclusion that identifying and quantifying subsidies in nonmarket economy countries is a hopeless task.

While it is easy to see that the implementation problem exists, its magnitude is nonetheless difficult to estimate. The degree of inaccuracy encountered in applying free-market principles to nonmarket economies depends largely on the method of application. To apply countervailing duty laws to nonmarket economy countries, the Department of Commerce is likely to substitute price and cost information from a comparable surrogate market economy for the information that does not exist in the nonmarket economy country. This method finds support in Article 15 of the Subsidies Code, which provides for the use of the surrogatecountry approach to calculate the value of a subsidy when conventional means are infeasible. ${ }^{180}$ Regulations proposed in the past by the De-

141 See GAO RePort to The Congress, supra note 1, at 2; Downey \& Graham, supra note 140 , at 438 .

${ }_{142}$ See Comment, supra note 9, at 222.

${ }^{143}$ See P. SAMUelson, supra note 1, at 821-23.

144 See GAO Report To THE Congress, supra note 1, at 2; Downey \& Graham, supra note 140 , at 438 .

${ }^{145}$ Steel from Czechoslovakia, supra note 114, at 19,371-72.

$14 \mathrm{Cf}$. P. Samuelson, supra note 1 , at 821 (noting that in the Soviet Union, "[t]he state owns almost all factors of production.").

${ }_{147}$ See Georgetown Steel Corp. v. United States, 801 F.2d 1308, 1315-16 (Fed. Cir. 1986); Recent Development, International Trade: Imposition of Countervailing Duty Laws on Products From Nonmarket Countries-Continental Steel Corp. v. United States, 27 HaRv. INT'L L.J. 745, 749 (1986).

${ }^{148}$ See Steel from Czechoslovakia, supra note 114, at 19,373.

149 See, e.g., Barceló, supra note 1, at 850; Hudec, Interface Revisited: "Unfair Trade" Policy After the Tokyo Round in InTERface Two, supra note 140, at 23; Soltysinski, Price Competition, supra note 10, at 20.

${ }_{150}$ See Georgetown Steel, 801 F.2d at 1317; Comment, supra note 14, at 329-30. Article 15(2) provides that:

It is understood that in [the case of nonmarket economy countries] the 
partment of Commerce also have advocated the use of surrogate-country procedures. ${ }^{151}$

A second factor influencing the magnitude of the implementation problem is the economy of the particular country under investigation. Just as there exists no pure free-market economy country, there is also no pure nonmarket economy country. The degree of central economic planning varies across nonmarket economy countries, ${ }^{162}$ and the current economic trend in many of these countries is to move away from strict state control and toward a free-market system. ${ }^{153}$ If this movement continues and results in prices and consolidated exchange rates that more accurately reflect the forces of supply and demand, the application of the free-market principles underlying the countervailing duty laws will be greatly facilitated. ${ }^{154}$ Moreover, movement toward a free-market economy would increase the accuracy with which surrogate-country procedures could be applied.

Thus, contrary to the conclusion reached by the Department of Commerce, the implementation problem does not render the application of countervailing duty laws to nonmarket economy countries a hopeless effort. Congress bridged the gap between free-market and nonmarket economies in 1974 when it applied the antidumping law to nonmarket economy countries through the use of surrogate-country and con-

calculation of the margin of dumping or of the amount of the estimated subsidy can be made by comparison of the export price with:

(a) the price at which a like product of a country other than the importing signatory . . . is sold, or

(b) the constructed value [] of a like product in a country other than the importing signatory ....

Subsidies Code, supra note 89 , art. 15(2), 31 U.S.T. at 538, T.I.A.S. No. 9619, at 21, GATT BISD, 26th Supp., at 74.

151 See, e.g., Proposed 19 C.F.R. § 155.4(a)(3), 44 Fed. Reg. 57,047 (1979) (valuing subsidized loans or guarantees by comparison to rates paid without government benefit by enterprises in a non-state-controlled economy at a comparable stage of economic development). These regulations were never adopted.

152 Yugoslavia, for example, is a communist country but is not universally recognized as a nonmarket economy country. See GAO REPORT TO THE CONGRESS, supra note 1 , at 1 . Yugoslavia's unique status is due to the country's movement away from state control and toward a free-market system. Cf. What's News-World-Wide, Wall St. J., March 25, 1988, at 1, col. 3 ("Yugoslavia's ruling body called for a 'radical' reduction of state interference in the economy.").

153 See P. Samuelson, supra note 1, at 819-21, 823-24; S. Soltysinski, U.S. Import Relief Laws, supra note 10, at 23; see also Berliner, Organizational Restructuring of the Soviet Economy in 1 JoInt Economic Comm., 100Th Cong., 1st Sess., Gorbachev's Economic Plans 70 (Comm. Print 1987) (discussing current plans to develop and invigorate the private sector in the Soviet economy); Schiffman \& Leung, China Cautiously Widens Experiments in Market Prices, Wall St. J., April 19, 1988, at 31, col. 3 (discussing the shift toward free-market pricing in the People's Republic of China); What's News-World Wide, supra note 152, at 1, col. 3.

${ }^{15}$ See Soltysinski, U.S. Import Relief Laws, supra note 10, at 23. 
structed value pricing methods. That same gap can be bridged today in the context of countervailing duties.

The true nature of the implementation problem is not that some insurmountable barrier prevents the equation of disparate economies, but rather that any such equation is inherently inaccurate. Thus, Congress must decide whether it will accept the degree of inaccuracy that would accompany application of the countervailing duty laws to nonmarket economy countries. Contrary to the conclusion of the courts and many scholars, there is no definitive solution.

\section{B. The Policy Problem}

The policy problem poses the question of whether the application of countervailing duty laws to nonmarket economy countries is consistent with United States trade policy. Like the implementation problem, the policy problem finds its roots in the differences between free-market and nonmarket economy countries. This Comment argues that because the economic impact of dumping and subsidization is indistinguishable in nonmarket economy countries, ${ }^{155}$ it would be irrational for the United States to apply both countervailing duty and antidumping laws to these countries.

One way of viewing the distinction between dumping and subsidization is to ask whether a decrease in the price of a good is absorbed by the firm or by the government. ${ }^{186}$ For example, if a Japanese producer sells its television sets in the United States at one dollar below the cost of production, and finances the loss by raising the product's price in Japan, it is engaged in dumping. ${ }^{157}$ But if the same producer sold its televisions at one dollar below cost and financed the loss with a government grant, the product would be subsidized by the government.

In a nonmarket economy, the government and the producer are, in

158 See J. Patrison, supra note $3, \S 18.05$, at 18-9 ("The closed nature of and strict unitary control implicit in centrally controlled economies means that scenarios may arise in which it is not possible to realistically determine whether the injury arising from an import from those economies comes from dumping or subsidies."); DiehIman, The EEC Anti-Dumping/Anti-Subsidy Policy: New Approaches to Old Problems? in INTERface Two, supra note 140, at 489, 502 (noting that the EEC law is based on the proposition that "the distinction between dumping and subsidization is useless with regard to imports from SCE countries").

${ }^{156} \mathrm{Cf}$. Note, supra note 14, at 597 n.3 (providing examples of dumping and subsidization).

167 The firm is dumping simply because of the price discrimination between the two markets. The fact that it is selling its televisions in the United States at less than the cost of production is not necessary to a finding of dumping. By definition, a producer is dumping when it charges a lower price for its product in a foreign market than it does in its domestic market. See supra note 4. 
theory, a single economic entity ${ }^{158}$-much like a parent corporation and its subsidiary. This unified economic identity clouds the distinction between subsidization and dumping. ${ }^{158}$ Consider, for example, a nonmarket economy producer of television sets. If the producer lowers the price of its exports to one dollar below cost, where is the loss absorbed? If the producer absorbs the loss through a domestic price increase, the action will be labeled dumping. Alternatively, if the state reimburses the producer for the loss, the action will be labeled subsidization. These labels, however, are easily reversed. For example, when the producer absorbs the loss through a domestic price increase, the action can also be considered subsidization, because in a nonmarket economy the state controls the price structure. Likewise, the state may finance a grant to the producer by mandating an increase in the product's domestic price. Thus, as one commentator noted, "[I]n [nonmarket economies] it can be argued strongly that 'subsidies' enable dumping to occur, and thus it could be argued that dumping and subsidies are but two sides of the same coin."180 Consequently, in the context of imports from nonmarket economy countries, attempts to categorize an unfair trading practice as either dumping or subsidization are meaningless. In a nonmarket economy, the two are indistinguishable.

Many commentators have noted this point. ${ }^{161}$ However, those commentators who focus on the implementation problem have failed to realize that absent any way of distinguishing between subsidization and dumping in nonmarket economies, the application of both antidumping and countervailing duty laws is irrational. The imposition of both laws would undercut the economic goal of the unfair trade laws: maximizing market efficiency by offsetting unfair trade practices. ${ }^{\mathbf{1 6 2}}$

The application of both antidumping and countervailing duty laws would afford domestic petitioners a choice of remedies for a single offense. The result of such a choice would be the substitution of countervailing duty petitions for antidumping petitions against nonmarket

158 See Note, supra note 1, at 410, 416-17.

158 By definition, an act of subsidization entails a transfer of some benefit from the state to a producer. See supra notes 103-06 and accompanying text.

160 Denton, supra note 74, at 236.

161 See, e.g., Rawson, An Outline of United States Regulation of Trade With Nonmarket Economy Countries, in INTERFACE Two, supra note 140, at 538 (noting that use of surrogate-country procedures in an antidumping case would, in effect, "transform a countervailing duty case into an antidumping case"); Comment, supra note 14, at 332 ("Adoption of the surrogate method would mean that antidumping and CVD [countervailing duty] petitions involving imports from NMEs would be almost identical."); Note, supra note 1, at 425 ("Subsidization and dumping are similar concepts in the nonmarket setting because there is no private sector of the economy.").

162 See supra notes 1-6 and accompanying text (discussing the market efficiency goals of United States trade laws). 
economy countries. This shift would occur because only a few nonmarket economy countries receive the benefit of an injury test under the United States countervailing duty laws. ${ }^{163}$ Under the antidumping laws, however, every country receives the benefit of this test. ${ }^{164}$ If petitioners are given a choice between filing under the antidumping laws or the countervailing duty laws, they will inevitably choose the former. ${ }^{165}$ The result of this choice would be that the injury test accorded by the antidumping law would become meaningless in trade relations with nonmarket economy countries. Furthermore, the number of petitions filed against nonmarket economy countries would increase, owing to the absence of a burden on the petitioner to demonstrate injury. To the extent that the countervailing duty laws could be applied to offset trading practices that are not causing any material injury to the United States economy, the unfair trade practice laws would become competitive weapons for domestic producers rather than efficiency-maximizing standards in international trade relations. ${ }^{168}$

This result would injure the United States' political and trade relations with nonmarket economy countries. According to one Eastern European commentator, to allow the application of countervailing duty laws without an injury test would imply that "the primary objective of [United States] trade laws is to eliminate or drastically reduce trade."167 By erecting such a barrier to imports from nonmarket economy countries, United States producers would begin using the countervailing duty laws as a competitive weapon, and might eventually eliminate a

${ }^{183}$ See GAO REPORT TO THE ConGRess, supra note 1, at 29. Hungary, Poland, People's Republic of China, and Romania are eligible for an injury test only on dutyfree imports. Albania, Bulgaria, Gzechoslovakia, the German Democratic Republic, and the Soviet Union are entirely ineligible for an injury test. See id. Ineligibility for an injury test acts as an incentive to sign the Subsidies Code or a like agreement, see supra text accompanying notes $90-93$, but the structure of nonmarket economies precludes these countries from signing the Code, rendering the ineligibility for an injury test an inescapable sanction. See GAO REPORT TO THE CONGRESS, supra note 1, at 30.

${ }^{164}$ See supra notes 40-41 and accompanying text.

${ }^{185}$ See GAO REPORT TO THE CongREss, supra note 1, at 30-31; Note, supra note 14 , at $627-28$.

${ }^{166} \mathrm{Cf}$. Barceló, supra note 1, at $844-47$ (discussing the importance of the injury test to the goal of free-trade efficiency).

${ }^{167}$ S. Soltysinski, U.S. Import Relief Laws, supra note 10, at 17 . Western commentators have arrived at similar conclusions. See, e.g., GAO REPORT TO THE CONGRESS, supra note 1, at 31 (describing the trade inhibiting effects that would result from the application of countervailing duty laws without the requirement of an injury test); Comment, U.S. Trade Laws Hinder the Development of U.S.P.R.C. Trade, 22 CoLUm. J. TransNat'L L. 135 (1983) (proposing the abandonment of countervailing duty law in favor of an injury-based approach); Note, supra note 1, at 424 (noting possible injury to trade by applying countervailing duty laws to nonmarket economy countries without an injury test). 
majority of successful nonmarket economy exporters. ${ }^{188}$ Furthermore, by impairing the ability of nonmarket economy countries to export to the United States, application of the countervailing duty laws to these countries would likely lead to retaliatory measures, thus harming domestic producers as well. ${ }^{\mathbf{1 6 9}}$

The implications of straining trade relations with nonmarket economy countries should not be understated. Such a policy clearly runs against the declared goal of promoting free-trade efficiency between nations. ${ }^{170}$ Moreover, the United States would be closing off a significant market-one that is only beginning to open to Western trade. ${ }^{171}$ The United States historically has enjoyed a favorable balance of trade with nonmarket economy countries, ${ }^{172}$ and significant political benefits and leverage attach to these relations. ${ }^{\mathbf{1 7 3}}$

Current law provides domestic producers a single offsetting duty to protect them from both dumping and subsidization by nonmarket economy countries. This scheme achieves all of the protective goals of the unfair trade laws, but avoids the excessive protection that application of both laws would engender.

Current law is also consonant with Article 15 of the Subsidies Code. ${ }^{174}$ Article 15 addresses the application of countervailing duty and antidumping laws to nonmarket economy countries, requiring signatories to choose between applying either antidumping laws or countervailing duty laws against nonmarket economy countries. ${ }^{175}$ In essence,

${ }^{168}$ See Soltysinski, Price Competition, supra note 10, at 22 n.69.

168 See GAO REPORT TO THE ConGRess, supra note 1, at 8-9.

${ }^{170} C f$. id. at 5 (defining U.S. objectives as "open and nondiscriminatory trade with all countries ....").

${ }^{171}$ In 1981, the nonmarket economy countries constituted approximately one third of the world's population, with a combined gross national product roughly equal to that of the United States. See GAO REPORT TO THE Congress, supra note 1, at 8; see also Heiss, U.S.-Soviet Trade Trends in 2 JoINT Economic Comm., supra note 153, at 455 ("From 1983 to 1985, the Soviet Union ranked in the top five (in 1984 it was 2nd) U.S. trade partners in terms of the surplus in the trade balance."); Farnsworth, C.I.A. is Cautious on China's Growth, N.Y. Times, May 2, 1988, at D8, col. 4 (noting China's development into "one of the world's leading exporters," as well as its growing demand for food imports).

172 See GAO REPORT TO Congress, supra note 1, at 3. But see Farnsworth, supra note 171 , at D8, col. 6 (noting China's current trade surplus with the U.S.).

173 See GAO REPORT TO CONGRESS, supra note 1, at 8-9.

174 See Subsidies Code, supra note 89, art. 15, 31 U.S.T. at 538, T.I.A.S. No. 9619 at 21, GATT BISD, 26th Supp., at 74-75; J. PATTISON, supra note 3, § 18.05, at 18-19 (noting that the Subsidies Code recognizes the absence of any distinction between dumping and subsidies in nonmarket economy countries.).

${ }^{175}$ See Subsidies Code, supra note 89, art. 15(1), 31 U.S.T. 513, 538, T.I.A.S. No. 9619, at 21; Georgetown Steel Corp. v. United States, 801 F.2d 1308, 1317 (Fed. Cir. 1986) (describing how Article 15 of the Subsidies Code provides a choice between countervailing duty law and antidumping law); see also Alford, supra note 10, at 111- 
this provision limits domestic producers in signatory countries to a single entitlement to relief from the unified unfair trade practice of subsidization and dumping by nonmarket economy countries. ${ }^{176}$

\section{ConCLuston}

As recent congressional efforts to invalidate the Georgetown Steel decision ${ }^{\mathbf{1 7 7}}$ demonstrate, there is significant support in Congress for proposals to reject the current scheme and apply both the antidumping and countervailing duty laws to countries with nonmarket economies. ${ }^{\mathbf{1 7 8}}$ In doing so, Congress would be rejecting the arguments put forth in Georgetown Steel and by many scholars that the problem of implementing these laws is too severe. Implicitly, Congress would be deciding that the benefit to domestic producers from applying these laws outweighs the inefficiencies resulting from the use of surrogate-country and constructed value methods to identify and quantify subsidies. This result would not be illogical; indeed, it would be consistent with Congress's decision to adopt these methods in implementing the antidumping law against nonmarket economy countries.

Congress's treatment of the policy problem, however, is not as convincing. It is not at all clear that Congress has considered the political and economic ramifications of applying the countervailing duty laws to nonmarket economy countries. The potential results-interference with the free-trade efficiency goals of United States trade law, and the

12 (discussing the nonmarket economy country choice provision of Article 15).

While Congress never specifically incorporated the requirements of Article 15 into domestic law, the United States laws are not inconsistent with Article 15. Legislative recognition of Article 15 would have entailed an act declaring that either the antidumping laws or the countervailing duty laws were to be applicable to nonmarket economy countries. Ostensibly, this would have been done in the Trade Agreements Act of 1979, in which the other restrictions of the Subsidies Code were enacted. Congress noted that it intended in this Act to make all of the necessary changes in United States law to implement the results of the Tokyo Round. See S. REP. No. 249, 96th Cong., 1st Sess. 1 , reprinted in 1.979 U.S. CODE CONG. \& AD. News 381. Congress's silence as to the application of countervailing duty laws to nonmarket economy countries-in contrast to the many amendments and regulations regarding the application of antidumping laws to these countries-was taken as a signal that it had chosen the antidumping laws as the mechanism for combatting unfairly priced imports from those countries. See $\mathrm{Ge}$ orgetown Steel, 801 F.2d at 1316-18; see also S. Soltysinski, U.S. Import Relief Laws, supra note 10, at 16-17 (discussing judicial declaration of nonapplicability of countervailing duty law to imports from nonmarket economy countries). The Georgetown Steel holding reinforced this interpretation. See Georgetown Steel, 801 F.2d at 1318 ("Congress elected to deal with the problem under the antidumping law and not under the countervailing duty law.").

${ }_{176}$ See Soltysinski, Price Competition, supra note 10, at 21.

${ }_{177}$ See supra notes 130-31 (listing efforts to invalidate Georgetown Steel).

178 See H.R. REP. No. 40, Part 1, 100th Cong., 1st Sess. 138-39 (1987). 
straining of important political and trade relations-call for a more serious consideration of this problem. 
